\title{
Engineering Site Investigation and Shallow Foundation Design in Ore Area of Ondo State, Nigeria
}

\section{Inženirsko kartiranje in načrtovanje plitvega temeljenja na območju Ore v zvezni državi Ondo, Nigerija}

\author{
Olumuyiwa, O. Falowo \\ Department of Civil Engineering Technology, Faculty of Engineering Technology, Rufus Giwa Polytechnic, Owo, \\ Ondo State, Nigeria \\ oluwanifemi.adeboye@yahoo.com
}

\begin{abstract}
The study integrates geophysical and geotechnical methods for subsoil evaluation and shallow foundation design. The study involved six vertical electrical sounding and geotechnical investigation involving cone penetration test and laboratory soil analysis. Three major geologic units were delineated; the topsoil, weathered layer and partly weathered/fractured/fresh bedrock. The overburden thickness is in between 15.2-32.9 m. Based on resistivity (16-890 ohm-m) and thickness (12.7-32 m) the weathered layer is competent to distribute structural load to underlying soil/rock. The groundwater level varies from 4.5 to $12.3 \mathrm{~m}$. Therefore an average allowable bearing capacity of $200 \mathrm{kPa}$ is recommended and would be appropriate for design of shallow foundation in the area, at a depth not less than $1.0 \mathrm{~m}$ with an expected settlement ranging from $9.03-48.20 \mathrm{~mm}$. The ultimate bearing and allowable bearing capacity for depth levels of 1-3 m vary from 1403-2666 kPa and 468-889 kPa for strip footing while square footing varies in between $1956-3489 \mathrm{kPa}$ and 652-1163 kPa respectively.
\end{abstract}

Key words: cone penetration test, vertical electrical sounding, settlement analysis, bearing capacity, Ore southwestern.

\section{Povzetek}

Raziskava se ukvarja $\mathrm{z}$ geofizikalnimi in geotehničnimi metodami za ocenjevanje plasti pod površjem in $\mathrm{z}$ načrtovanjem plitvega temeljenja. $\mathrm{V}$ raziskavo je bilo vključenih šest navpičnih električnih sondiranj in geotehničnih preiskav, kot so preizkus s statičnim konusnim penetrometerom (CPT) in laboratorijske preiskave zemljin. Razmejene so bile tri glavne geološke enote; zgornja plast tal, preperela plast in delno preperela/razpokana/sveža podlaga. Debelina nadkritja je med 15.2-32.9 m. Na osnovi upornosti (16-890 ohm-m) in debeline (12.7-32 m) je preperela plast ustrezna za prenos konstrukcijske obtežbe na nižje ležečo zemljino/kamnino. Gladina podtalnice niha med 4.5 do $12.3 \mathrm{~m}$ pod površjem. Zato je priporočena povprečna dovoljena nosilnost $200 \mathrm{kPa}$, ki bi bila primerna za načrtovanje plitvega temeljenja na tem območju, z globino ne manj kot $1.0 \mathrm{~m}$ in s pričakovanim posedanjem v območju med 9.03-48.20 mm. Mejne in dovoljene nosilnosti pasovnih temeljev za globine 1-3 m so $1403-2666 \mathrm{kPa}$ in 468-889 kPa, za kvadratne temelje pa $1956-3489 \mathrm{kPa}$ in $625-1163 \mathrm{kPa}$.

Ključne besede: preizkus s statičnim konusnim penetrometrom, navpično električno sondiranje, analiza posedkov, nosilnost tal, JZ Ore. 


\section{Introduction}

Shallow Foundations are usually located no more than six feet below the lowest finished floor [1-3]. A shallow foundation system generally used when the soil close the ground surface has sufficient bearing capacity, and underlying weaker strata do not result in undue settlement. The shallow foundations are commonly used most economical foundation systems. Footings are structural elements, which transfer loads to the soil from columns, walls or lateral loads from earth retaining structures. In order to transfer these loads properly to the soil, footings must be design to: prevent excessive settlement; minimize differential settlement; and provide adequate safety against overturning and sliding. Deep foundations are usually used when the conditions of the upper soil layers are weak and unable to support the superstructure loads [4]. Piles carry these superstructure loads deep in the ground. Therefore, the safety and stability of pile supported structures depend on the behavior of piles [5-6]. Most soil deposits in Ore are soft in nature.

There are different methods commonly used in assessing the in-situ geo-mechanical properties of the soil; the use of geophysical techniques, such as electrical resistivity method (VES) or seismic method; direct probing using static or dynamic penetration techniques and or boreholes. The success in the applicability of geophysical techniques depends on so many factors. The most important one is that there must be significant and detectable contrast between the physical properties of the different units in the subsurface, such as velocity, electrical resistivity, conductivity, density, acoustic properties, subsurface geology and the environmental conditions. Among these techniques, electrical resistivity method has a lots of applications: evaluation of temperature of soil and water content, evaluation of soil salinity, groundwater and mining survey and geotechnical investigation and geological mapping [7-9]. In addition, the 1D electrical method had been improved to a two dimensional imaging of the subsurface [10-11]. More recently, D-C electrical resistivity methods had been used for environmental studies [12] soil characterization for engineering purposes [13] and mapping of growth fault.
In addition cone penetration test (CPT) is considered the most frequently used method for characterization of geomedia [14-16]. The CPT is basically advancing a cylindrical rod with a cone tip into the soil and measuring the tip resistance and sleeve friction due to this intrusion. The resistance parameters are used to classify soil strata and to estimate strength and deformation characteristics of soils. The CPT is a simple, quick, and economical test that provides reliable in situ continuous soundings of subsurface soil [17-19]. Due to the soft nature of soil deposits in Ore, Ondo State, Nigeria the CPT is considered a perfect perfect tool for the area's site characterization. In subsurface exploration, the CPT in conjunction with SPT or in correlation with laboratory analysis of samples have effectively used to identify and classify soils and to evaluate the undrained shear strength. Implementation of the CPT can drastically decrease the number of soil borings and reduce the cost and time required for subsurface characterization. Following the standardization of test procedure [20] and improvement on the method of data interpretation [21], its reliability is found to be excellent. Mechanical cone, electric cone, and piezocone are the devices commonly used in cone penetration testing. The mechanical type is least efficient and least sensitive to changes in soil conditions, sensitive to changes in soil conditions. The goals of this research is to identify and estimate the bearing capacity of the subsoil layering through geophysical, cone penetration test data, and laboratory sampling analysis, for design of foundation and bases [22] in the study area.

\section{Material and Methods}

\section{Description of the Study Area}

The study area is Odigbo Local Government of Ondo State. The area can access through Akure - Ore Lagos - Benin highways and is located within latitude $715000-75500 \mathrm{mN}$ and longitude 664750-725000 mE (Figure 1). Major part of the study area is devoted to agricultural and commercial activities. The study area falls within the tropical rainforest climate. The average temperature is $25{ }^{\circ} \mathrm{C}$. Relative humidity of the area differs within $70 \%$ to $80 \%$. The av- 


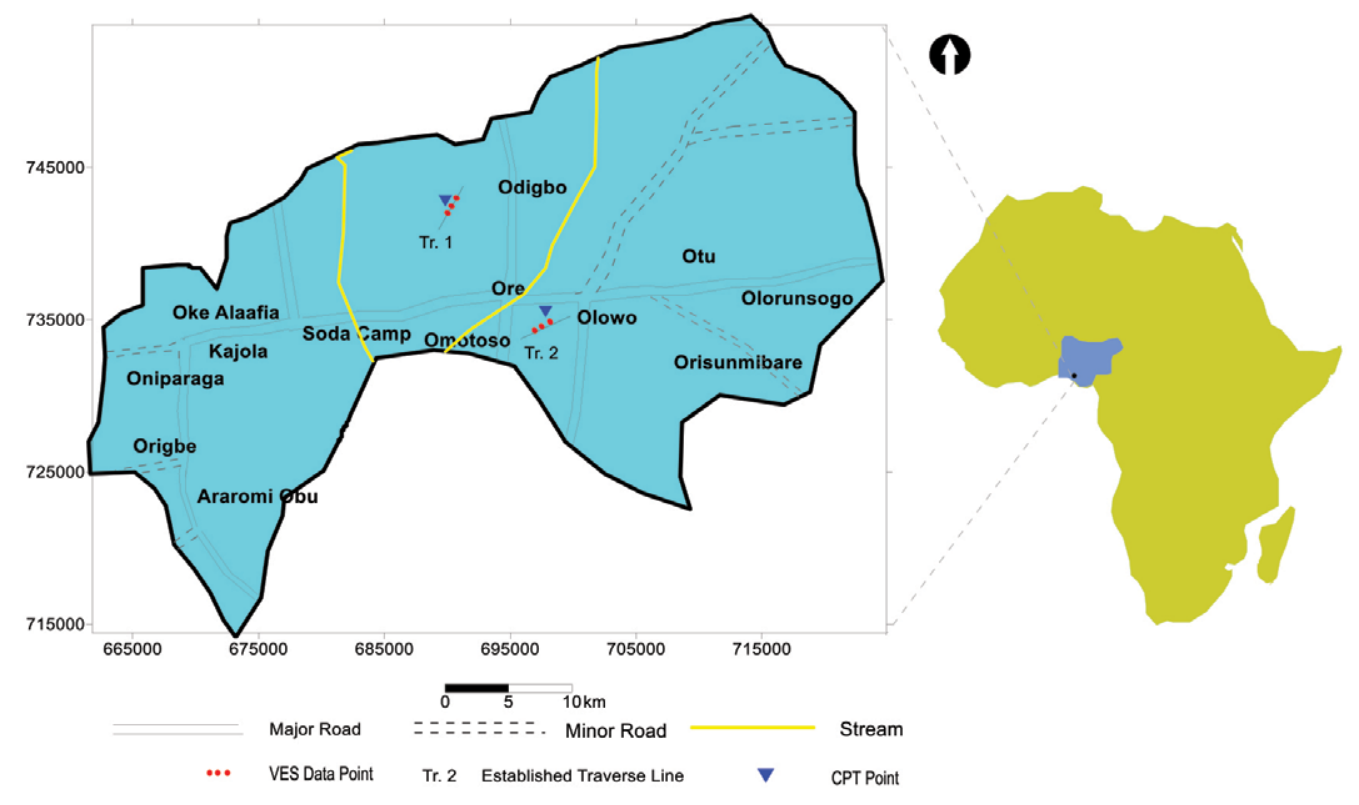

Figure 1: Location Map showing data acquisition points.

erage annual rainfall of the study area is about $1500 \mathrm{~mm}$ and $2500 \mathrm{~mm}$ [23]. The topographic elevation ranges from 110-185 m. The northern area falls within the geologic terrain, underlain by the Precambrian basement complex rocks of southwestern Nigeria, characterized by the migmatite-gneiss complex, older granites, charnockites, quartzite and minor intrusive lithologies [24-25]. The local geology consists of charnockite, fine grained biotite granite and gneiss in the north (Figures 2 and 3). Field observation shows that biotite granites in the area occur as large igneous bodies, and largely coarse grained. However the southern parts of the study area is underlain by Coastal plain sands of Benin formation; Ewekoro and Akinbo; and Abeokuta formations (Figure 2).

The Abeokuta Formation in surface outcrops comprises mainly sand with sandstone, siltstone, silt, clay, mudstone and shale interbeds. It usually has a basal conglomerate which may measure about $1 \mathrm{~m}$ in thickness and generally consists of poorly rounded quartz pebbles with a silicified and ferruginous sandstone matrix or a soft gritty white clay matrix. In outcrops where there is no conglomerate, coarse, poorly sorted pebbly sandstone with abundant white clay constitutes the basal bed. The overlying sands are coarse grained, clayey, micaceous and poorly sorted, and indicative of short distances of transportation or short duration of weathering and possible derivation from the granitic rocks located to the north. The Ewekoro Formation overlies the Araromi Formation in the eastern Dahomey basin (Figure 2). It is an extensive limestone body, which is traceable over a distance of about $320 \mathrm{~km}$ from Ghana in the west, towards the eastern margin of the Dahomey basin in Nigeria. Okosun [26] has reported that the limestone is of shallow marine origin owing to abundance of coralline algae, gastropods, pelecypods, echinoid fragments and other skeletal debris. It is Paleocene in age. Overlying the Ewekoro Formation is the Akinbo Formation, which is made up of shale and clayey sequence [27]. The claystones are concretionary and are predominantly Kaolinite. The base of the Formation is defined by the presence of glauconitic band with lenses of limestone [26-27]. The Formation is Palaeocene to Eocene in age. The area is well drained by rivers and streams that flow in the same direction as the rock strike. These streams take their source from relatively high elevation about $200 \mathrm{~m}$ above the mean sea level and flow downhill along the strike into valleys.

\section{Data Collection and Analysis}

Subsurface investigations employing geophysical techniques are of paramount importance in assessing the suitability of an area for the con- 


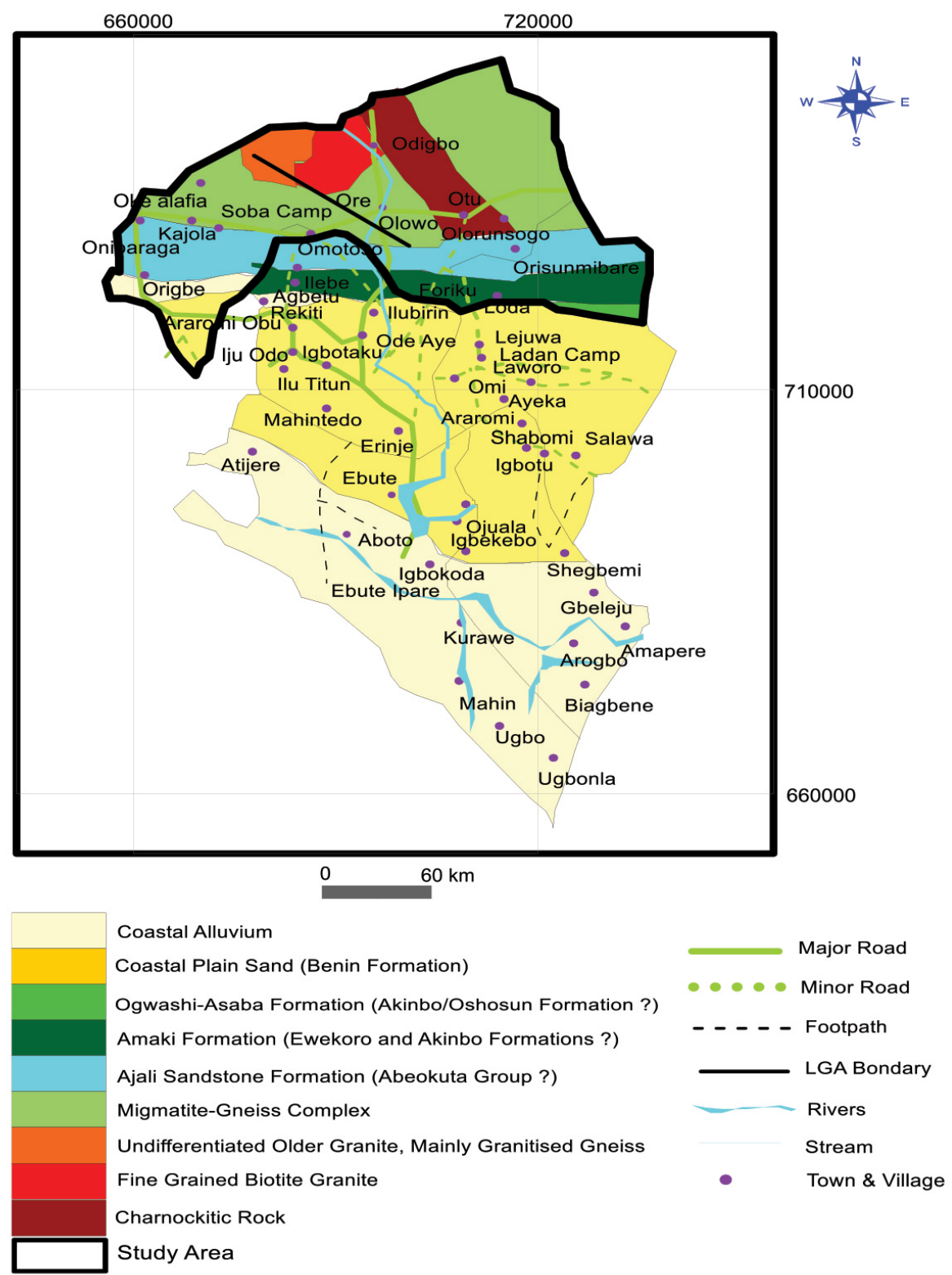

Figure 2: Geological map of Southern part of Ondo State.

struction of buildings, roads, bridges, etc. The method has been proven to be an effective tool for identifying anomalies and defining the complexity of the subsurface geology [10-28]. The electrical imaging or electrical tomography is a survey technique recently developed for the investigation of areas of complex geology. Electrical resistivity imaging was carried out along two established traverses in $\mathrm{N}$ - S direction and six VES were conducted in order to delineate the resistivity of the subsurface materials. The technique was used so as to delineate the overburden, weathered zones, fractured columns and where possible, the bedrock at the site. Six (06) Schlumberger vertical electrical soundings (VES) were conducted across the study area using a maximum current electrode separation (AB) of $100 \mathrm{~m}$. Figure 1 shows the VES locations. Resistivity measurements were made with a digital resistivity meter (Ohmega) which allows for readout of current (I) and voltage (V). The field curves were interpreted through partial curve matching with the help of master curves and auxiliary point charts 


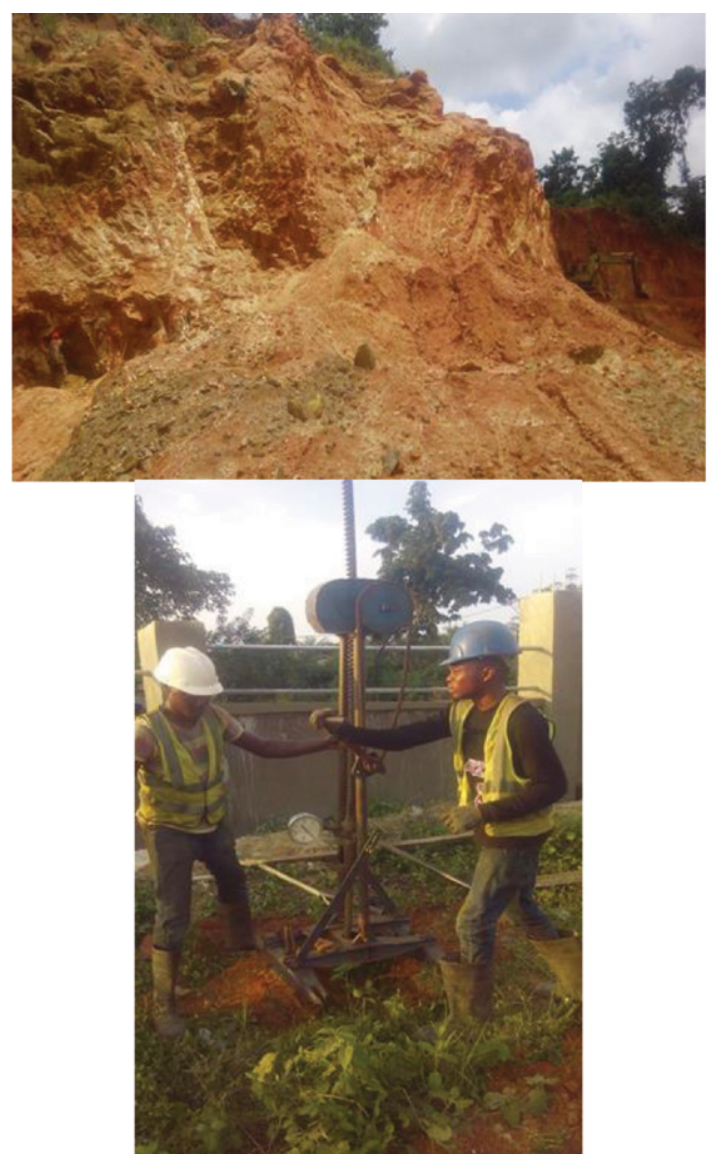

Figure 3: Field Pictures of the thick lateritic clay deposit in Odigbo and Cone penetration test.

[29-30]. From the preliminary interpretation, initial estimates of the resistivity and thickness of the various geoelectric layers at each VES location were obtained. These geoelectric parameters were later used as starting model for a fast computer-assisted interpretation [31-32]. The program takes the manually derived parameter as a starting geoelectric model, successively improved on it until the error is minimized to an acceptable level. Cone penetration tests were performed at a total of six (6) locations within the study area (Figure 1). The tests were carried out to a depth of $3 \mathrm{~m}$. The Dutch static penetration measures the resistance of penetration into soils using a $60^{\circ}$ steel cone with an area of $10.2 \mathrm{~cm}^{2}$.

The cone penetrometer test is a means of ascertaining the resistance of the soil. The layer sequences are interpreted from the variation of the values of the cone resistance with depth.
The test is carried out by securing the winch frame to the ground by means of anchors. These anchors provided the necessary power to push the cone into the ground. The cone and the tube are pushed together into the ground for 20 to $25 \mathrm{~cm}$; the cone is pushed ahead of the tube for $3.5 \mathrm{~cm}$ at a uniform rate of about $2 \mathrm{~cm} / \mathrm{sec}$ [33-34]. The resistance to the penetration of the cone registered on the pressure gauge connected to the pressure capsule is recorded. The tube is then pushed down and the procedure described above repeated. From the series of recorded gauge readings, cone resistance and sleeve friction are plotted against depth.

The layer sequences were interpreted from the variation of the values of the cone resistance with depth. The allowable bearing pressure of the soil layers on each location was calculated using Meyerhof [35] and Schmertmann [36] equation direct method for estimating ultimate bearing capacity $\left(\mathrm{q}_{u l t}\right)$ from cone resistance for square and strip footings, as shown in equations (1) to (5):

$q_{u l t}=q_{c}\left(\frac{B}{12.2}\right)\left(1+\frac{D_{f}}{B}\right)$

$q_{c}=$ cone resistance value

$D_{f}=$ Depth of footing

$B=$ Width of foundation

Factor of safety at least 3 is recommended by Meyerhof to obtain the allowable bearing pressure.

For cohensionless soils:

Strip $q_{u l t}=\left[\left(28-0.0052\left(300-q_{c}\right)^{1.5}\right] 98 \mathrm{kPa}\right.$

Square $q_{u l t}=\left[\left(48-0.0052\left(300-q_{c}\right)\right)^{1.5}\right] 98 \mathrm{kPa}(3)$

For clay:

Strip $q_{u l t}=\left(2+0.28 q_{c}\right) 98 \mathrm{kPa}$

Square $q_{u l t}=\left(5+0.34 q_{c}\right) 98 \mathrm{Kpa}$

All samples obtained in the field were carefully preserved and subjected to more detailed visual inspection and descriptions at the laboratory. Thereafter, representative samples were 
selected from each stratum for laboratory analysis in accordance with relevant geotechnical engineering standards including BS 1377 [37]. The disturbed soil samples were appropriately subjected to the following laboratory classification tests: natural moisture content; Atterberg limits (liquid and plastic limits); grain size analysis; and unconsolidated undrained triaxial tests at different cell pressures. Sieve analysis of cohesive soils were done by soaking oven-dried samples in water overnight and washing through sieve No. 200 (75 microns opening) while remnants retained on sieve No. 200 were oven-dried and sieved mechanically. Materials finer than sieve number 200 were analyzed using the hydrometer method based on Stoke's Law. Total consolidation settlement (s) has been computed for foundation breadth (B) between $0.5-3.0 \mathrm{~m}$, subjected to an allowable bearing capacity of $100 \mathrm{kPa}$. The induced vertical stress $(\Delta \sigma)$ at the centre of the consolidating layer has been used in computing $\mathrm{s}$. The final consolidation settlement has been computed from the expression below [38] using Equation (6):

$s=m_{v} H \Delta \sigma^{\prime}$

$m_{v}=$ coefficient of volume compressibility

$H=$ thickness of compressible layer

$\Delta \sigma^{\prime}=$ average increase in effective pressure which was varied from $0.02-0.16 \mathrm{MPa}$

An average $m_{v}$ value of $0.125 \mathrm{~m}^{2} / \mathrm{KN}$ which corresponds to the adopted net allowable bearing capacity, was used in the settlement analysis and also corresponds to stiff clay (with compression index of 0.15 to 0.06 ), although this was based on the result of the laboratory experiment performed on the soil samples within the study area. The value of $m_{v}$ adopted also corresponds to the range given by [39] of $0.25-0.125 \mathrm{~m}^{2} / \mathrm{KN}$. Coefficient of volume compressibility $\left(\mathrm{m}_{\mathrm{v}}\right)$ is more useful parameter than coefficient of permeability, because for a particular soil $m_{v}$ is not constant but depends on the pressure range considered.

\section{Results and Discussion}

The VES curves identified in the area are $\mathrm{H}$, $\mathrm{QH}$, and KH types with three to four geoelectric layer combinations. The $\mathrm{QH}$ curve type predominates, constituting $50 \%$ of the total, the $\mathrm{KH}$ curve type constitutes $33.3 \%$ and $\mathrm{H}$ curve type constitute $16.7 \%$. The geoelectric section along Traverse 1 in Odigbo (Figure 4) identified maximum of four geoelectric/geologic subsurface layers comprising the topsoil, weathered layer, partly weathered/fractured basement/fresh basement. The topsoil varies in composition from clay to clayey sand, sandy clay and lateritic clay with resistivity values ranges from 68 to 689 ohm-m and thickness varies from $0.9-2.5 \mathrm{~m}$. The resistivity of this layer has average of $200 \mathrm{ohm}-\mathrm{m}$ whose geoelectric characteristic is typical of sandy clay. The weathered layer resistivities are generally within the range of 46 and $890 \mathrm{ohm}-\mathrm{m}$, typical of clay, clayey sand, and laterite. Resistivity in the range of $40-200 \mathrm{ohm}-\mathrm{m}$ is the most dominant, signifying a clayey weathered layer, The thickness is moderately thick with values varying from $12.7 \mathrm{~m}$ to $20.5 \mathrm{~m}$ and generally. The partly weathered/fractured basement/fresh basement has layer resistivity values vary from 882-1464 ohm-m. The depth to (overburden thickness) this layer is in between 15.2-22.1 m. Information gathered from existing hand dug well and boreholes shows that the groundwater level varies from 7.4 to $9.5 \mathrm{~m}$. Therefore the weathered layer could be stabilized prior construction to improve the geotechnical properties since it's predominantly clayey. This would reduce consolidation settlement usually associated with clay. The thickness of the topsoil is very thin to accommodate civil engineering foundation structure because the upper $1 \mathrm{~m}$ is usually removed during construction to guide against undue settlement arising from buried/ decayed plants and animals. The groundwater level ranges between $4.5-6.2 \mathrm{~m}$.

Along Traverse 2 in Ore metropolis, the geoelectric section (Figure 5) also delineates maximum of four geoelectric/geologic subsurface layers comprising the topsoil, weathered layer, partly weathered/fractured basement/fresh basement. The topsoil has resistivity values ranging from 69 to $228 \mathrm{ohm}-\mathrm{m}$ and thickness 


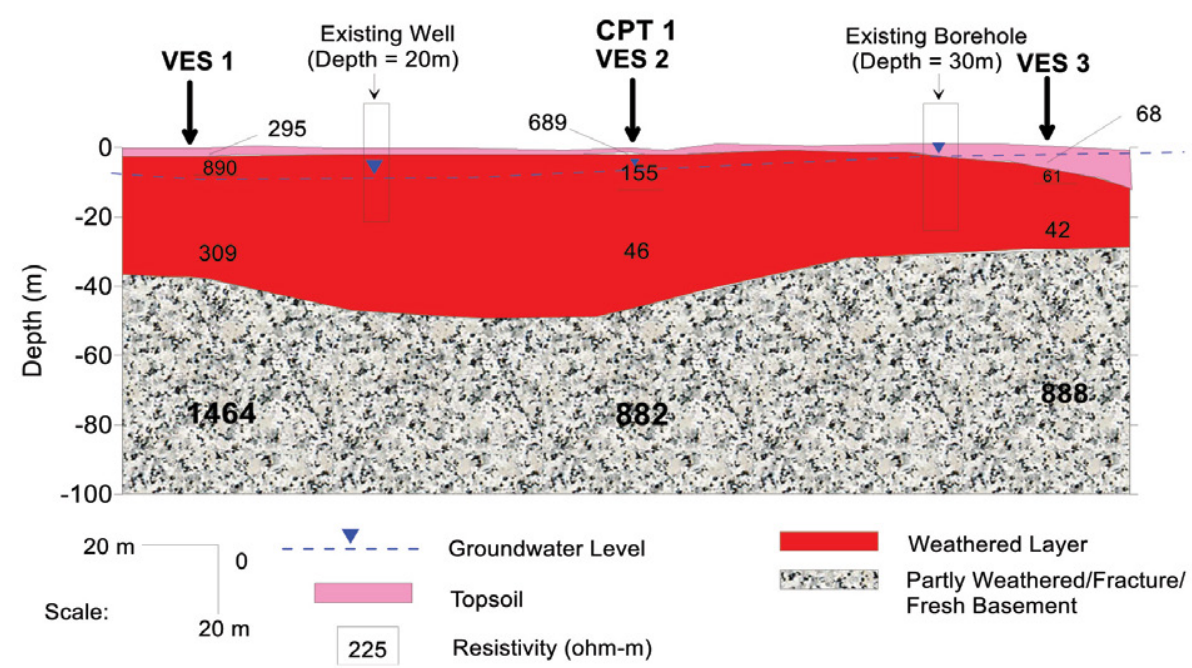

Figure 4: Geoelectric Section along Traverse 1 in Odigbo.

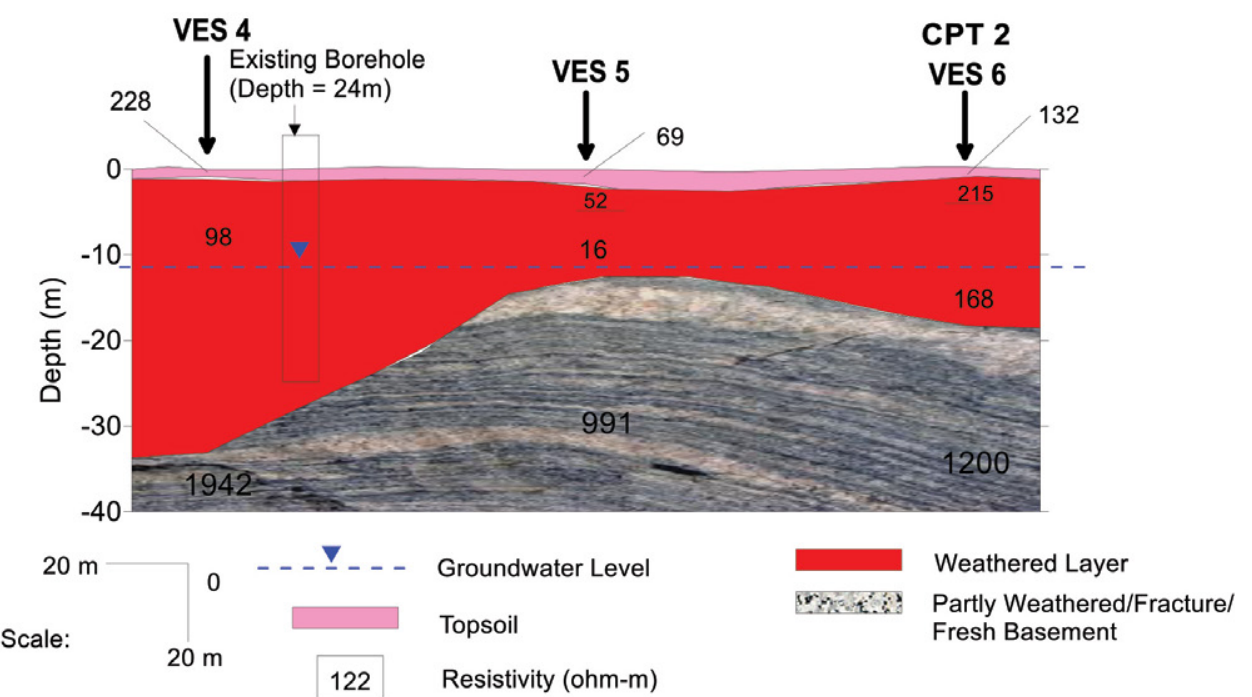

Figure 5: Geoelectric Section along Traverse 2 in Ore.

varies from $0.9-2.0 \mathrm{~m}$. It varies in composition from clay to clayey sand. The weathered layer resistivities are generally within the range of 16 and 215 ohm-m, typical of clayey soil. The thickness is moderately thick with values varying from 17.5 to $32 \mathrm{~m}$. The partly weathered/ fractured basement/fresh basement has layer resistivity values vary from 991-1200 ohm-m. This is the major aquifer in the area especially where the fracture basement is extensive with high fracture density/lineament interception. The depth to (overburden thickness) this layer is in between $19.5-32.9 \mathrm{~m}$. The groundwater level measured from an existing well along this Traverse under VES 4/VES 5 records $12.3 \mathrm{~m}$. Consequently this water level may not pose any/serious threat to foundation structure in the area. Therefore the weathered layer thickness is thick enough to distribute structural load to underlying soil/basement rock. But appreciable degree of stabilization (especially mechanical stabilization) to improve the geotechnical properties since it's predominantly clayey. This would also reduce consolidation settlement usually associated with clay soil material. 
Table 1: Geotechnical/Engineering Properties of soil in location 1.

\begin{tabular}{cccccccccccccc}
$\begin{array}{c}\text { Depth } \\
\text { (m) }\end{array}$ & $\begin{array}{c}\text { Cone } \\
\text { Resistance }\end{array}$ & $\begin{array}{c}\text { Sleeve } \\
\text { Resistance }\end{array}$ & $\begin{array}{c}\text { Friction } \\
\text { Ratio }\end{array}$ & $\begin{array}{c}\text { L.L } \\
\text { (\%) }\end{array}$ & $\begin{array}{c}\text { P.L } \\
\text { (\%) }\end{array}$ & $\begin{array}{c}\text { P.I } \\
\text { (\%) }\end{array}$ & $\begin{array}{c}\text { S.L } \\
\text { (\%) }\end{array}$ & $\begin{array}{c}\text { M.C } \\
\text { (\%) }\end{array}$ & $\begin{array}{c}\text { \% } \\
\text { Gravel }\end{array}$ & $\begin{array}{c}\text { \% } \\
\text { Sand }\end{array}$ & $\begin{array}{c}\text { \% } \\
\text { Silt }\end{array}$ & $\begin{array}{c}\text { \% } \\
\text { Clay }\end{array}$ & S.G \\
\hline 0.2 & 20 & 35 & 1.75 & 30.5 & 20.3 & 10.2 & 9.9 & 6.3 & 0.1 & 25.3 & 56.9 & 17.7 & 2.65 \\
\hline 0.4 & 40 & 60 & 1.50 & & & & & & & & & & \\
\hline 0.6 & 58 & 70 & 1.21 & 27.2 & 19.4 & 7.80 & 6.3 & 10.5 & 0.2 & 44.6 & 43.5 & 11.7 & 2.65 \\
\hline 0.8 & 50 & 60 & 1.20 & & & & & & & & & & \\
\hline 1.0 & 62 & 70 & 1.13 & 35.8 & 20.9 & 14.9 & 10.2 & 12.6 & - & 22.0 & 54.9 & 22.8 & 2.65 \\
\hline 1.2 & 70 & 90 & 1.29 & & & & & & & & & \\
\hline 1.4 & 85 & 120 & 1.41 & 34.1 & 19.8 & 14.3 & 11.8 & 12.2 & - & 28.4 & 63.3 & 8.4 & 2.65 \\
\hline
\end{tabular}

Table 2: Geotechnical/Engineering Properties of soil in location 2.

\begin{tabular}{|c|c|c|c|c|c|c|c|c|c|c|c|c|c|}
\hline $\begin{array}{l}\text { Depth } \\
\text { (m) }\end{array}$ & $\begin{array}{c}\text { Cone } \\
\text { Resistance }\end{array}$ & $\begin{array}{c}\text { Sleeve } \\
\text { Resistance }\end{array}$ & $\begin{array}{l}\text { Friction } \\
\text { Ratio }\end{array}$ & $\begin{array}{l}\text { L.L } \\
(\%)\end{array}$ & $\begin{array}{l}\text { P.L } \\
\text { (\%) }\end{array}$ & $\begin{array}{l}\text { P.I } \\
(\%)\end{array}$ & $\begin{array}{l}\text { S.L } \\
(\%)\end{array}$ & $\begin{array}{l}\text { M.C } \\
\text { (\%) }\end{array}$ & $\begin{array}{c}\% \\
\text { Gravel }\end{array}$ & $\begin{array}{c}\% \\
\text { Sand }\end{array}$ & $\begin{array}{c}\% \\
\text { Silt }\end{array}$ & $\begin{array}{c}\% \\
\text { Clay }\end{array}$ & S.G \\
\hline 0.2 & 20 & 30 & 1.50 & 41.6 & 24.1 & 17.53 & 7.9 & 11.8 & - & 32.0 & 31.2 & 36.8 & 2.70 \\
\hline 0.4 & 35 & 50 & 1.43 & & & & & & & & & & \\
\hline 0.6 & 50 & 70 & 1.40 & 51.7 & 30.1 & 21.61 & 9.1 & 18.7 & - & 43.6 & 20.8 & 35.6 & 2.69 \\
\hline 0.8 & 60 & 85 & 1.42 & & & & & & & & & & \\
\hline 1.0 & 60 & 90 & 1.50 & 57.3 & 37.4 & 19.93 & 8.6 & 16.8 & - & 36.9 & 28.9 & 34.1 & 2.69 \\
\hline 1.2 & 100 & 140 & 1.40 & & & & & & & & & & \\
\hline
\end{tabular}

The summary of the geotechnical results is shown in Tables 1 and 2 .

The $\%$ gravel ranges from $0.1-0.2$, sand varies in between $22-44.6 \%$, \% silt varies from 20.8-63.3, and clay ranges from 8.4-36.8\%. Generally the soil is dominated by sandy silt (SM). The average clay content in the soil is less than 35\% which falls within 35\% recommended for subsoil material that are good for civil engineering foundation construction. The specific gravity of the soil recorded values in the range of 2.65 (sand)-2.70 (clay). The average percentage passing $0.075 \mathrm{~m}$ is $33.3 \%$ which falls within $35 \%$ recommended for subsoil material that are good for construction. The engineering parameters of the soil samples are within the federal ministry of works and housing [40] specification for civil engineering building foundation construction. The analyzed soil samples at both locations shows liquid limits of $27.2-57.3 \%$ (avg. 39.7\%), plastic limits of 19.4-37.4\% (avg. 24.57\%), plasticity index of
7.80-21.61\% (avg. 15.18\%) and shrinkage limits of $6.3-11.3 \%$ (avg. 9.1\%) indicating moderate soil quality [41-42]. Generally, the lower the linear shrinkage, the lesser the tendency for the soil to shrink when desiccated [41-42]. The natural moisture content ranges from $6.3-18.7 \%$ (avg. $12.7 \%$ ) which is moderately low. The FMWH [40] recommends liquid limit of $50 \%$ maximum, plastic limit of $30 \%$ maximum, plastic index of $20 \%$ maximum and $8 \%$ maximum for foundation material. Hence, the soil can be adjudged as a good foundation soil. The results of cone resistance with depth shows increase in cone resistance and sleeve resistance with depth (Tables 1 and 2), range from $20-85 \mathrm{~kg} / \mathrm{cm}^{2}$ and $35-120 \mathrm{~kg} / \mathrm{cm}^{2}$ at CPT 1 , and $20-100 \mathrm{~kg} / \mathrm{cm}^{2}$ and $30-140 \mathrm{~kg} / \mathrm{cm}^{2}$ at CPT 2 respectively. The friction ratio ranges from 1.13-1.75 (CPT 1) and 1.40-1.50 (CPT 2). The Robertson [43] soil chart classification (Figure 6) shows two dominant zones of 6 to 7 corresponding to sandy silt to clayey silt and silty 


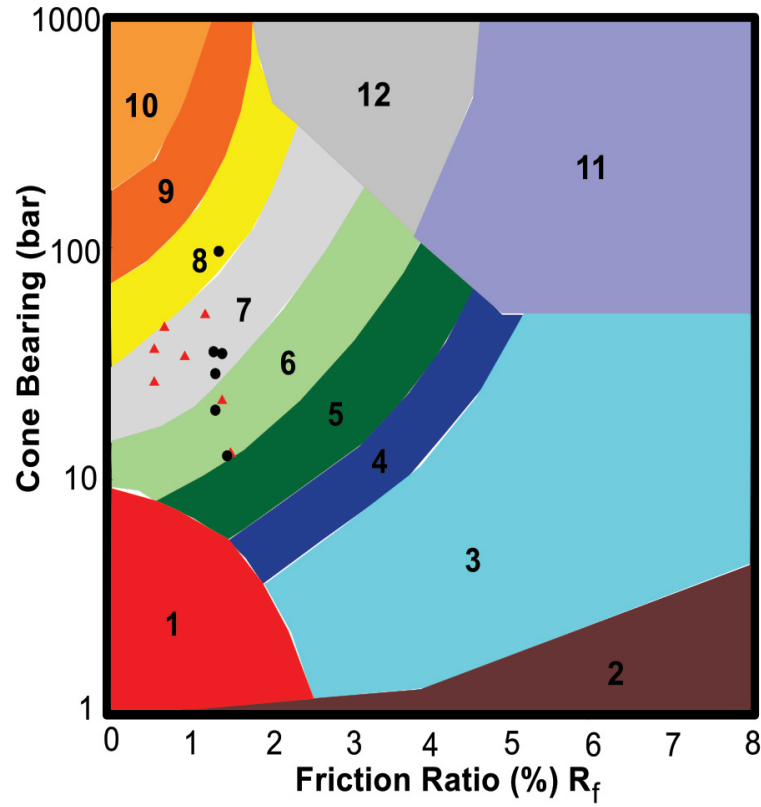

\begin{tabular}{|c|c|l|}
\hline Zone & $q_{c / N}$ & \multicolumn{1}{|c|}{ SBT } \\
\hline 1 & 2 & Sensitive, fine grained \\
2 & 1 & Organic materials \\
3 & 1 & Clay \\
4 & 1.5 & Silty clay to clay \\
5 & 2 & Clayey silt to silty clay \\
6 & 2.5 & Sandy silt to clayey silt \\
7 & 3 & Silty sand to sandy silt \\
8 & 4 & Sand to silty sand \\
9 & 5 & Sand \\
10 & 6 & Gravelly sand to sand \\
11 & 1 & Very stiff fine grained \\
12 & 2 & Sand to clayey sand \\
\hline
\end{tabular}

*Over consolidated or cemented

- CPT at Location 1

- CPT at Location 2

Figure 6: Robertson Chart for the soil classification using cone resistance and friction ratio values.

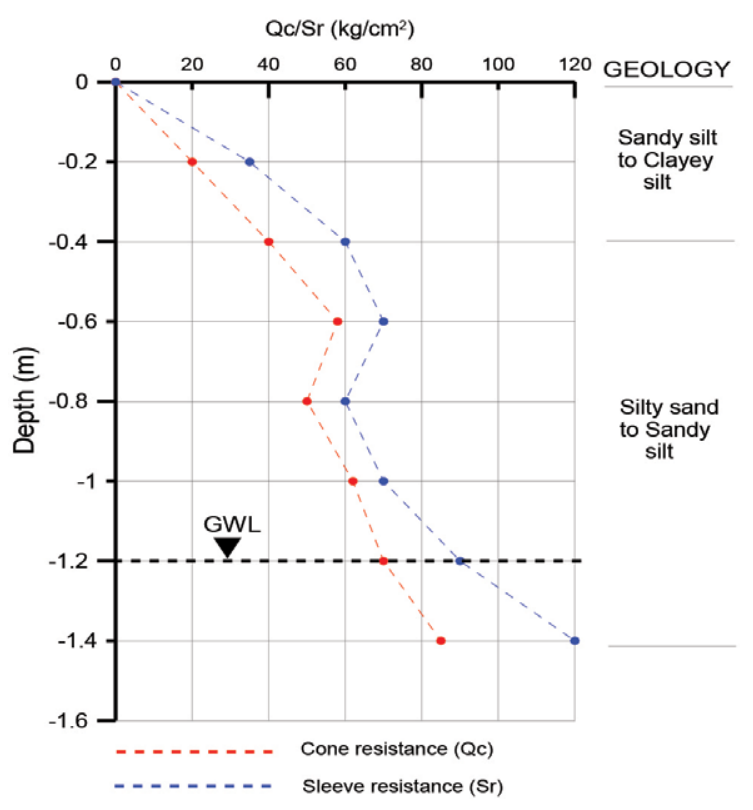

(a)

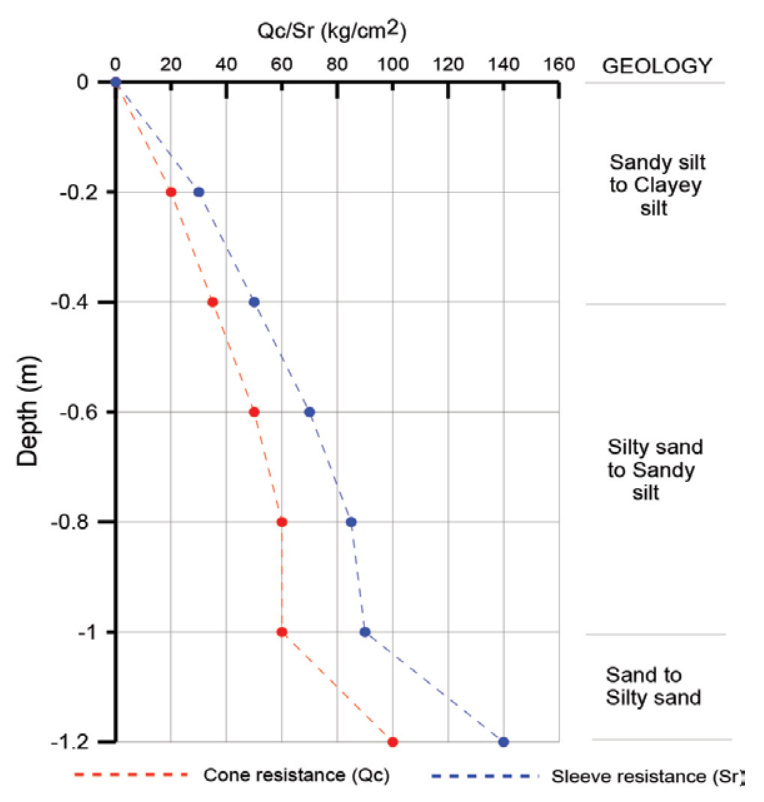

(b)

Figure 7: Plots of Cone resistance and sleeve resistance against depth at location 1 and 2, corresponding to (a) Odigbo CPT 1 (b) Ore CPT 2.

sand to sandy silt respectively (Figure 7). The plots of cone resistance and sleeve resistance against depth (Figure 8) showed two geological succession of sandy silt to clayey silt $(0-0.4 \mathrm{~m})$ and silty sand to sandy silt $(0.4-1.4 \mathrm{~m})$ at CPT 1 and three geologic sequence in CPT 2, namely sandy silt to clayey silt (0-0.4 m), and silty sand to sandy silt (0.4-1.0 m). Consequently, at least depth of $1.0 \mathrm{~m}$ would be appropriate as found- 
Table 3: Bearing Capacities estimated from the Cone resistance values for both sites (locations).

\begin{tabular}{ccccc} 
& \multicolumn{3}{c}{ CPT 1 } & \multicolumn{3}{c}{ CPT 2 } \\
\cline { 2 - 5 } Depth (m) & $\mathbf{( k P a )}$ & $\mathbf{( k P a )}$ & $\mathbf{( k P a )}$ & $\mathbf{( k P a )}$ \\
\hline 0.2 & 49 & 147 & 49 & 147 \\
\hline 0.4 & 98 & 294 & 86 & 257 \\
\hline 0.6 & 142 & 426 & 123 & 368 \\
\hline 0.8 & 123 & 368 & 147 & 441 \\
\hline 1.0 & 152 & 456 & 147 & 441 \\
\hline 1.2 & 172 & 515 & 245 & 735 \\
\hline 1.4 & 208 & 625 & - & - \\
\hline
\end{tabular}

Table 4: Settlement variation at Different Depths and Foundation Widths.

Settlement (mm) at Depth Level (m)

\begin{tabular}{cccc}
\cline { 2 - 4 } Foundation width (m) & $\mathbf{1 ~} \mathbf{~ m}$ & $\mathbf{3 ~ m}$ \\
\hline 0.6 & 43.97 & 45.64 & 48.20 \\
\hline 1.2 & 24.49 & 27.20 & 30.70 \\
\hline 1.5 & 20.13 & 23.07 & 26.82 \\
\hline 2.0 & 14.53 & 17.54 & 21.33 \\
\hline 3.0 & 9.03 & 12.32 & 16.21 \\
\hline
\end{tabular}

Table 5: Bearing Capacities for Strip and Square Shallow Foundations in the Study area.

\begin{tabular}{ccccc}
\multirow{2}{*}{ Depth (m) } & Strip & Square & Strip & Square \\
\cline { 2 - 5 } & $\mathbf{( k P a )}$ & $\mathbf{( k P a )}$ & $\mathbf{( k P a )}$ & $\mathbf{( k P a )}$ \\
\hline 1 & 1403 & 1956 & 468 & 652 \\
\hline 2 & 1870 & 2523 & 623 & 841 \\
\hline 3 & 2666 & 3489 & 889 & 1163 \\
\hline
\end{tabular}

ing depth for design and construction of shallow foundation in the area.

The ultimate and allowable bearing capacity estimated from the cone resistance using Meyerhof [35] equation are presented in Table 3. The calculated bearing capacities could be used in determining the foundation type for structures. The allowable bearing of the soil varies between 49 to $208 \mathrm{kPa}$ for CPT 1, and $49-245 \mathrm{kPa}$ for CPT 2 and ultimate bearing capacity of 147 to $625 \mathrm{kPa}$ and 147 to $735 \mathrm{kPa}$ respectively. Consequently an average allowable bearing capacity of $200 \mathrm{kPa}$ (ultimate bearing capacity of
$600 \mathrm{kPa}$ ) is recommended and would be appropriate for design of shallow foundation in the area, at a depth not less than $1.0 \mathrm{~m}$ in location 1 and $1.4 \mathrm{~m}$ at location 2 .

Settlement and bearing capacity are the major factors that govern foundation design. The commonly accepted basis of design is that the total settlement of a footing should be restricted to about $25 \mathrm{~mm}$ [34], [42-44] as by so doing the differential settlement between adjacent footings is confined within limits that can be tolerated by a structure. The settlement analysis for foundation width of $0.6-3.0 \mathrm{~m}$ at three depth 
levels of $1 \mathrm{~m}, 2 \mathrm{~m}$ and $3 \mathrm{~m}$ produces values between 30.06-45.92 mm (Table 4). But foundation width above $1.5 \mathrm{~m}$ produces settlement less than $25 \mathrm{~mm}$ (Table 5) recommended by Bell [42] as it ranges between $9.03-21.33 \mathrm{~mm}$. Although according to Meyerhof [35], Schmertamnn [36] total settlement limits of $60 \mathrm{~mm}$ (clay) and $50 \mathrm{~mm}$ (granular soil) are still tolerable [45]. Therefore foundation width not less than $1.5 \mathrm{~m}$ for depth not less than $0.6 \mathrm{~m}$ is still feasible and appropriate. The calculation of bearing capacities for strip and square foundation is shown in Table 5. For strip foundation, the appropriate (recommended) ultimate bearing and allowable bearing capacity for depth levels of 1-3 m vary from $1403-2666 \mathrm{kPa}$ and $468-889 \mathrm{kPa}$, while square footing varies in between $1956-3489 \mathrm{kPa}$ and $652-1163 \mathrm{kPa}$ respectively (Table 6).

\section{Conclusion}

Subsoil evaluation and shallow foundation design have been carried out in Ore area of Ondo State, Nigeria for civil engineering structure using geophysical and geotechnical method of investigations. The investigation was able to provide information on the stratigraphy, nature, structural disposition, competence of the subsoil. It also recommended appropriate foundation bearing capacities and corresponding expected settlements for different footing sizes and founding depths. The VES curves identified in the area are $\mathrm{H}, \mathrm{QH}$, and $\mathrm{KH}$ types with three to four geoelectric layer combinations. The $\mathrm{QH}$ curve type predominates, constituting $50 \%$ of the total, the KH curve type constitutes 33.3\% and $\mathrm{H}$ curve type constitute $16.7 \%$. The investigation delineated four geologic layers which include the topsoil, weathered layer, partially weathered/fractured basement/fresh bedrock. The groundwater level measured from an existing well and borehole ranged from 4.5-12.3 m. Consequently this water level may not pose any/serious threat to foundation structure in the area. Therefore the weathered layer thickness is thick enough to distribute structural load to underlying soil/basement rock. But appreciable degree of stabilization (especially mechanical stabilization) to improve the geo- technical properties since it's predominantly clayey. This would also reduce consolidation settlement usually associated with clay soil material. All the determined geotechnical parameters of the subsoil fall within the specification recommended for foundation material by FMWH. In view of this, an average allowable bearing capacity of $200 \mathrm{kPa}$ (ultimate bearing capacity of $600 \mathrm{kPa}$ ) is recommended and would be appropriate for design of shallow foundation in the area, at a depth not less than $1.0 \mathrm{~m}$ in location 1 and $1.4 \mathrm{~m}$ at location 2 . This would produce settlement values ranging from 9.03-48.20 mm depending on the width of the foundation. The ultimate bearing and allowable bearing capacity for depth levels of 1-3 m vary from $1403-2666 \mathrm{kPa}$ and $468-889 \mathrm{kPa}$ for strip footing while square footing varies in between 1956-3489 $\mathrm{kPa}$ and 652-1163 kPa respectively.

\section{References}

[1] Das, B.M. (1983): Advanced soil mechanics. Hemisphere Publishing Corporation: Washington, DC, $51 \mathrm{p}$.

[2] Teng, W.C. (1962): Foundation Design. Prentice-Hall International, Inc.: Englewood Cliffs, N.J., 119 p.

[3] Peck, R.B., Hanson, W.E., Thornburn, T.H. (1953): Foundation Engineering. John Wiley \& Sons, Inc.: New York, 243 p.

[4] Terzaghi, K., Peck, R.B. (1967): Soil Mechanics in Engineering Practice, 2nd edition. John Wiley \& Sons, Inc.: New York, $491 \mathrm{p}$.

[5] Garg, S.K. (2009): Soil mechanics and foundation engineering, 7th revised edition. Khanna Publishers: New Delhi, 752 p.

[6] Vesic, A.S. (1963): Bearing capacity of deep foundation in sand. Highway Research Method. No. 39, pp. 112-153.

[7] Olorunfemi, M.O., Idonigie, A.I., Coker A.T., Babadiya, G.E. (2004): The Application of the Electrical Resistivity Method in Foundation Failure Investigation. A Case Study of O.A.U. Ile-Ife, Dental Clinic. Global Journal of Geophysical Science, 2(1), pp. 139-151.

[8] Oyedele, K.F., Olorode, D.0. (2010): On Site Investigation of Subsurface Conditions using Electrical Resistivity Method and Cone Penetration Test at 'Medina Brook Estate, Gbagada, Lagos, Nigeria. World Applied Science Journal, 11(9), pp. 1097-1104. 
[9] Oyedele, K.F., Bankole, O.O. (2009): Subsurface Stratigraphic Mapping using Geophysics and its impact in urbanization in Arepo area, Ogun State, Nigeria. New York Science Journal, (5)2, pp. 31-45.

[10] Loke, M.H., Barker, R.D. (1996): Rapid least-squares inversion of apparent resistivity pseudosections by a quasi-Newton method. Geophysical Prospecting 44, pp. 131-152.

[11] Badmus, B.S., Akinyemi, O.D., Olowofela, J.A., Folarin, G.M. (2012): 3D electrical resistivity tomography survey for the basement of the Abeokuta terrain of Southwestern Nigeria. J. Geol. Soc. India, 80, p. 845, DOI: $10.1007 / \mathrm{s} 12594-012-0213-x$.

[12] Sharma, P.V. (1997): Environmental and Engineering Geophysics. Cambridge University Press, p. 173.

[13] Olayanju, G.M., Mogaji, K.A., Lim, H.S., Ojo, T.S. (2017): Foundation integrity assessment using integrated geophysical and geotechnical techniques: case study in crystalline basement complex, southwestern Nigeria. Journal of Geophysics and Engineering 14(3), pp. 675-690.

[14] ISOPT-1. (1988): Cone penetration test. International reference test procedure. In: Proceedings of the First International Symposium on Penetrating Testing, ISOPT-1, Orlando California, de Ruiter, J. (ed.). A.A. Balkema: Rotterdam; Brookfield.

[15] Huijzer, G.P. (1990): Automated stratigraphic classification of CPT data. In: Proceedings 6th International Congress IAEG, Amsterdam, Price, D.G (ed.). A.A. Balkema: Rotterdam; Brookfield, pp. 309-311.

[16] Juang, C.H., Huang, X.H., Holtz, R.D., Chen, J.W. (1996): Determining relative density of sands from CPT using fuzzy sets. Journal of Geotechnical Engineering, 122(1).

[17] Harder, H., Von, B.V. (1988): Determination of representative CPT parameters. Penetration testing in the UK. In: Proceedings of the Geotechnology Conference, Birmingham, Telford, T. (ed.). London, pp 237-240.

[18] Broms, B.B. (1986): Penetration tests. In: Proceedings of the 4th International Geotechnical Seminar, Singapore. Nanyang Technological Institute: Singapore.

[19] Biddle, D.W. (1989): Penetration testing in the UK. In: Proceedings of the Geotechnology Conference, Birmingham, Telford, T. (ed.). London, pp 189-191.

[20] Owuama, C.O. (2000): A comprehensive method of interpretation of static cone data. NSE Technical Transactions, 35(1), pp. 53-66.

[21] Lunne, T., Robertson, P.K., Powell, J.J.M. (1997): Cone Penetration Testing in Geotechnical Practice. Blackie Academic and Professional: London, 312 p.
[22] Schmertmann, J. H. (1970): Static Cone to Compute Static Settlement over Sand. Journal of the Soil Mechanics and Foundations Division, 96(SM3), pp. 1011-1043.

[23] Iloeje, M.P. (1981): A new Geography of Nigeria. Longman: Nigeria, pp. 26-28.

[24] Rahaman, M.A. (1982): Review of the Basement Geology of Southwestern Nigeria. In: Geology of Nigeria, Kogbe C.A. (ed.). Elizabethan Pub. Co.: Lagos, pp. 41-58.

[25] Jones, H.A., Hockey, R.D. (1964): The geology of part of Southwestern Nigeria. Geological Survey of Nigeria, Bull. 31, p. 87.

[26] Okosun, E.A. (1998): Review of the Early Stratigraphy of Southwestern Nigeria. Journal of Mining and Geology, 34(1), pp. 27-35.

[27] Omatsola, M.E., Adegoke, O.S. (1981): Tectonic evolution and cretaceous stratigraphy of the Dahomey Basin. Nigerian Journal of Mining and Geology, 18(1), pp. 130-137.

[28] Zhdanov, M.S., Keller, G.V. (1994): The Geoelectrical methods in geophysical exploration. Elsevier: Amsterdam, $873 \mathrm{p}$.

[29] Keller, G.V., Frischknecht, F.C. (1966): Electrical Methods in Geophysical Prospecting. Pergamon Press: Oxford, 519 p.

[30] Telford, W.M., Geldart, L.P., Sheriff, R.E. (1990): Applied Geophysics, 2nd edition. Cambridge University Press: Cambridge, 792 p.

[31] Sirles, P. (2006): Advancement in 3D Subsurface Modelling using Seismic Refraction Data- A new perspective. In: Proceedings for GEOPHYSICS 2006, 3rd International Conference on Applied Geophysics, St. Louis MO.

[32] Cosenza, P., Marmet, E., Rejiba, F., Cui, Y.J., Tabbagh, A., Charlery, Y. (2006): Correlations between geotechnical and electrical data: a case study at Garchy in France. Journal of Applied Geophysics, 60, pp. 165-178.

[33] Robertson, P.K., Campanella, R.G. (1983): Interpretation of cone penetration test part 1 sand. Canadian Geotechnical Journal, 30(4), pp. $734-745$.

[34] Mazlan, A. (2007): Correlation between Cone Penetration Test and Bearing Capacity for Shallow Foundation. Master's Thesis. Universiti Teknologi Malaysia.

[35] Meyerhof, G.G. (1976): Bearing capacity and settlement of pile foundations. ASCE Journal of the Geotechnical Engineering, 12(GT3), pp.194-228.

[36] Schmertmann, J.H. (1978): Guidelines for Cone Penetration Test, Performance and Design. U.S. De- 
partment of Transportation, Report No. FHWATS-78-209, Washington, D.C., p.145.

[37] British Standard Institutions (1990): Methods of Test for soils for Civil Engineering Purposes. B.S 1377: Part 2, 1990, pp. 8-200.

[38] Stroud, M.A., Butler, F.G. (1975): The standard penetration test and the engineering properties of Glacial materials. In: Proceedings of the Symposium of glacial materials, University of Birmingham.

[39] Upadhyay, A.K. (2015): Soil and Foundation Engineering, Second Edition. S.K. Kataria \& Sons: New Delhi, $245 \mathrm{p}$.

[40] Federal Ministry of Works and Housing (1972): Highway Manual Part 1 Road Design, Federal Ministry of Works and Housing: Lagos.

[41] Jegede, G. (2000): Effect of soil properties on pavement failure along the F209 highway at Ado-Ekiti,
Southwestern Nigeria. Journal of Construction and Building Materials, 14, pp. 311-315.

[42] Bell, F.G. (2007): Engineering Geology. Elsevier, $352 \mathrm{p}$.

[43] Robertson, P.K. (1990): Soil classification using the cone penetration test. Canadian Geotechnical Journal, 27, pp. 151-158.

[44] Vesic, A.S. (1967): Ultimate loads and settlement of deep foundations in sand. In: Proc. Symp. bearing capacity and settlement of foundations. Duke University, pp 53-68.

[45] Eslami, A., Gholami, M. (2002): Bearing capacity of shallow foundations from CPT data. In: Proceeding of 3rd Iranian International Conference on Geotechnical Engineering and Soil Mechanics, pp. 93-97. 